\title{
Shakespeare in French literary historiography
}

\section{Holger Klein}

\section{(2) OpenEdition \\ Journals}

Electronic version

URL: http://journals.openedition.org/shakespeare/580

DOI: 10.4000/shakespeare.580

ISSN: 2271-6424

\section{Publisher}

Société Française Shakespeare

\section{Printed version}

Date of publication: 1 November 2000

Number of pages: 109-118

ISBN: 2-84269-407-4

\section{Electronic reference}

Holger Klein, «Shakespeare in French literary historiography », Actes des congrès de la Société française Shakespeare [Online], 18 | 2000, Online since 01 November 2007, connection on 30 April 2019. URL : http://journals.openedition.org/shakespeare/580 ; DOI : 10.4000/shakespeare.580 
${ }^{3}$ Jauss does not distinguish such categories in his seminal essay of 1970, nor does Holub, to name a more recent contribution. Grimm (1975, p. 73) reports on Horst Steinmetz distinguishing between «produktive und [...] urteilende Rezeption», which could be squared with my «creative» and «critical»; Link's term «reproduzierende» reception (p. 78ff.) strikes me as ambiguous if not indeed misleading. Grimm's second book (1977) is at least clear, but does not offer practical terms either.

${ }^{4}$ Pellissier later wrote a tract against the Shakespeare cult: Shakespeare et la superstition shakespearienne (Paris: Hachette, 1914), cf. Dávidházi (p. 185).

5 «And what should they know of England who only England know? line 2 from «The English Flag» in Barrack-Room Ballads (1892, 68th edn 194), pp. 174-9.

${ }^{6}$ There are, of course, sections and chapters on criticism and literary history in some literary histories - I particularly liked the one by Moreau, which I read in the 1957 version of his book (pp. 338-57). However, for my specific subject, such sections do not yield much. See, however, Moreau's remarks on pp. 349 and 353 . The nearest thing to my project are the first sections of Brunel's very instructive as well as inspiring Claudel et Shakespeare, ch. I, sections i and ii (pp. 11-21).

${ }^{7}$ See Klemperer (1926), pp. 20-2, but also Duchet in Abraham / Desné's Manuel, vol. V : 1848-1917 (p. 117), who adduces the briefer criticism of Taine by Edgar Quinet ; cf. also Lanson (1898, pp. 1029-30) and Dumesnil (pp. 260-6). About Taine in general see Wolfzettel, pp. 208-23 (specifically 222 about Sh.) and, even more thoroughly, Wellek (vol. IV, pp. 27-57).

${ }^{8}$ See e.g. Lemercier (vol. I, p. 102 generally, and Voltaire with reference to Comedy (Lettres philosophiques, XIX), rather surprisingly endorsed, it seems, by Pomeau / Ehrard (p. 365). Vinet, discussing Chateaubriand (whose religious bent he shares), stresses the difficulties a foreigner encounters but argues that, save for some aspects, the poet, though «éminemment français» did, thanks to his «génie largement humain», penetrate and feel «le génie anglais» (vol. I, p. 486). In her opening remarks, Willems also refers to this imaginary barrier, which still seems to exist (p. 7).

${ }^{9}$ While Wolfzettel does discuss approaches and methods - as does, to a lesser extent, Brockmeier in his study - the actual manner of treatment, which could only be demonstrated by concentrating on specific cases, could clearly not figure in their conceptually illuminating surveys.

${ }^{10}$ E.g. those united in Yale French Studies 33 (1965) and Shakespeare Yearbook V (1994), or monographs like Charles M. Haines, Shakespeare in France from Voltaire to Hugo (London: Oxford U.P., 1925), or even more specialised works such as Thomas R. Launsbury, Shakespeare and Voltaire 
(New York: Scribner, 1902, repr. New York: Blom, 1968), Margaret Gilman, Othello in France (Paris : Champion, 1925), Helen Bailey Phelps, Hamlet in France from Voltaire to Laforgue (Geneva : Droz, 1964), Pierre Brunel's Claudel and Shakespeare (see below, Works Cited), and Gaston Hall, «French Hamlets», New Comparison 2 (Autumn 1986) : Hamlet at Home and Abroad, pp. 42-57; finally, research surveys like those by Fluchère and Maguin. One book I should very much have liked to consult in this context is Albert Lacroix, Histoire de l'influence de Shakespeare sur le théâtre français (1856), mentioned by A. C. Keys in «Shakespeare en France : La Mégère Apprivoisée en 1767», Revue de littérature comparée 31 (1957), pp. 426-8 (here 426).

${ }^{11}$ Thanks are due to the staff of the Bayerische Staatsbibliothek and the Universitätsbibliothek in Munich, the Französische Bibliothek of the Munich department of Romance Studies, and the Universitätsbibliothek Augsburg (in particular $\mathrm{Dr}$ Anton Schneider), furthermore at the Bibliothèque de l'Arsenal in Paris and the Bibliothèque Universitaire in Tours.

${ }^{12}$ Many of the titles listed and discussed in Wolfzettel cannot really qualify as literary histories. On the other side of the fence, Wellek cannot help considering also literary historians ; indeed, the inception of French modern literary history is an event in the history of criticism (see esp. vol. I, p. 29 and vol. II, p. 237).

${ }^{13}$ This could not have been put in this way in the first edn (1844); I suspect it was introduced into the 6th edn (1877), which I have not seen. I have used the 15th edn (1889), where the sentences occur in vol. IV on p. 509.

${ }^{14}$ For Stendhal within the framework of Romantic historiography see the article by François Rigolot in Hollier (pp. 632-44).

${ }^{15}$ Harvey's Companion does have a short entry, e.g., for Goethe, but none for Dante. Also Charlton's Companion (a differently structured book, not a dictionary) had Goethe, but neither Dante nor Shakespeare in the Index - something remedied in the revised Howarth / Peyre / Cruickshank publication of the literature chapters. The Germans seem more intent on separation, e.g. Wilfried Engler's Lexikon has no entries for either Shakespeare or Goethe, or any other foreign author - much like the second earliest French example I have seen: Taillefer. His work is organised exclusively by authors. A different kind, more in the wake of the Encyclopédie (and thus peripheral for my purposes here) is the Dictionnaire de la littérature by de Castres, which is organised by literary genres and terms, and thus comparative in concept. Shakespeare figures, e.g., in the article «Élocution», vol. I, p. 544ff., while he is absent from the similar dictionary (that it is, despite its title Essais) by Géruzez (1839).

${ }^{16}$ Pomeau / Ehrard (p. 357) assign «une perspective déjà comparatiste» also to Voltaire's Essai sur la poésie épique (originally published in English, 
1727) ; but see Wellek (vol. I, pp. 32-3, esp. 33).

${ }^{17}$ This was quite common in the old huge series of Ward and Waller (1907-16); also the chapter breakdown in Sampson / Churchill in the Contents pages shows, in ch. III «Renascence and Reformation» an entry for «Early German Influences on English Literature», and two sections on translation later on (pp. 173-8, 485-7). There are portions on translation in the volumes of The Oxford History of English Literature written by C. W. Lewis ( Drab Age Prose - Religious Controversy and Translation», pp. 157-221) and Douglas Bush («Popular Literature and Translations», pp. 39-75), also, offering a wide conspectus, in Sola Pinto (pp. 177-92), roughly corresponding to the chapter on translations in Lanson (Troisième Partie, livre II, chap. III, pp. 269-74). I have found nothing of the kind in the later volumes of The Oxford History of English Literature, nor in Baugh, nor - to name a recent example - Sanders. Perhaps the tide is turning again now, I note in Carter / McRae sections on «French influence and English affirmation» (pp. 15-29, about Middle English) and on Bible translation (pp. 78-85 - cf. Lewis). Clearly one would have to look further into this before pronouncing a definite opinion. For German, I have looked at Martini and many volumes of Helmut de Boor / Richard Newald. Again, more evidence would be needed to confirm my impression.

${ }^{18}$ See also e.g. Abry / Audic / Crouzet, Adam / Lerminier / Morot-Sir, Barbéris / Duchet (vol. IV, 1), Braunschvig, Dédier / Hazard, Delon / Mauzi / Menant, Duchet (Histoire, vol. IX), Henriot, Mesnard, and Sabatier. As a representative of the opposite extreme Daniel Mornet may serve - not with his general history (1924), which does include brief surveys of, and references to, relations with foreign literatures - but with his Littérature contemporaine may serve - he does not even list any foreign authors save a few that are important for the general intellectual and scientific background like Darwin and Freud. By contrast, Picon's Index has quite a few such authors, Shelley, Hawthorne, etc. - but forgets Shakespeare (who figures in the text) ; the index omission was rectified in the German edition.

${ }^{19}$ Histoire (gen. ed. Abraham / Desné), vol. VII (1976), p. 91 ; see the same text in the Manuel (gen. ed. Abraham / Desné), p. 402. (The doubling of these two series is rather confusing).

${ }^{20}$ Julleville is more constructive here than Nisard (vol. II, p. 95) on the same subject.

${ }^{21}$ Michel and Jeanne Charpentier (pp. 390-1): the funeral orations of Antony from Julius Coesar, III.2 (in the translation by Maurice Castelain, 1973) and from Voltaire's La mort de César, III.8 ; also Dominique Rincé and Bernard Lecherbonnier (pp. 129-30): Hamlet's soliloquy in Hamlet, III.1 and Hernani's soliloquy in Hugo's Hernani, III.4.

22 These events have been often discussed; see e.g. Charvet (1967), p. 147, Levi (vol. II, p. 539), Lioure (p. 68), Moreau (p. 75), Pellissier 
(pp. 98-9), Van Tieghem (pp. 194-5). Bédier / Hazard, however, see nationalism more than balanced by other forces (vol. II, p. 203). On the eventual change of the critical climate see e.g. Cruickshank (19th Century, p. 133).

${ }^{3}$ Bernard Gensane (Poitiers) tells me that Napoleon called the English «un peuple de boutiquiers», which might account for Geoffroy's phrase and similar ones; but I have been unable to track this down.

${ }^{24}$ Whom Berthaut (p. 367) defends against the charge of chauvinism; I bow to his superior knowledge of Geoffroy, but hardly think the phrase I picked out can be the only instance. On Geoffroy's neoclassical and hence anti-Shakespearean taste see Wellek (vol. II, pp. 218-9).

25 Adam Smith, An Inquiry into the Nature and Causes of the Wealth of Nations (1776), IV.7.41 (in the 1828 edn), see The Oxford Dictionary of English Proverbs (Oxford: Clarendon Press, 1935, 3rd edn rev. by F.P. Wilson, 1970), pp. 224-5. Napoleon's version, the Dictionary informs us, of it was mentioned in The Times on 17 Feb. 1911. I am grateful to my friend Bernard Gensane (Poitiers) who put me on to this. It is most likely, of course, that Geoffroy was guided by Napoleon, and the German expression may also derive from him, at least indirectly.

26 See also Barbéris / Duchet (vol. IV, 1), pp. 405-6, and esp. 464, where they say the 1822 demonstrations were directed not only «contre les acteurs anglais» but also «contre Shakespeare». p. 108.

${ }^{27}$ See also Des Granges, pp. 320-1 and 602, furthermore e.g. Mesnard,

${ }^{28}$ Among the histories I have read, perhaps the most empathetic account of de Staël is found in Didier (ch. VI, pp. 253-61); yet she underestimates de Staël's neoclassical taste and does not sufficiently consider the climatic and social environment factors that are so vital for de Staël's theories. See e.g. Charvet (19th Century, pp. 37-9) and Wellek (vol. II, pp. 219-31, esp. 220 and 229) - easily the least empathetic account I have come across - which makes it no less instructive and does not impair its justice. Cf. however, also the sober and kinder (though less theoretically underpinned) discussion by Lanson (pp. 874-85). Wellek thinks her later treatise De l'Allemagne (1810, pr. 1814) vastly superior to De la littérature (pp. 224-5), but see also Thibaudet, esp. pp. 50-1.

${ }^{29}$ Voltaire felt there were deep reasons for the absolute and unique supremacy, starting with the qualities of the French language; see Folkierski (p. 31).

${ }^{30}$ Michèle Duchet / J.M. Goulemot (p. 106) appositely quote from Rousseau's Considérations sur le gouvernement de Pologne (1771) : «Il n'est plus aujourd'hui de Français, d'Allemands, d'Espagnols, d'Anglais même [sic !], quoi qu'on en dise; il n'y a que des Européens». See also e.g. Lagarotti's letter to the Abbé Franchini prefixed to La mort de César in 
Voltaire, Théâtre, vol. II (Paris : Garnier, n.d.), pp. $312-5$ (here 313). Cf. in general Folkierski : «[...] le XVIIIle siècle. Il commence sous les auspices de la littérature française ; il finit sous ceux de la littérature européenne» (p. 31). See also Jasinski, vol. II, pp. 17, 54-5, 255. Vier justly reminds us that Prévost was not only an early admirer of Shakespeare but generally had a strong European dimension in his concepts (XVIIIe siècle, p. 382). Mornet throws cold water on notions of a European dimension to French literature in the late eighteenth and early nineteenth centuries, the Romantic period, saying that «La littérature tend à devenir véritablement européenne. Ne disons pas d'ailleurs qu'elle altère ou empoisonne le génie français. En realité, les Français ne subissent rien ou à peu près rien ; ils choisissent et ils adaptent» (Histoire, pp. 182-3). And as far as he is concerned, that is a good thing, one gathers.

${ }^{31}$ Quoted in Bédier / Hazard (vol. II, p. 293).

${ }^{32}$ In Sabatier, see esp. vol. V, 1 (XIXe siècle), pp. 51-5 «Regard vers l'Angleterre romantique», in which Milton and Spenser are evoked, before Sabatier comes to Young and Gray and the English Romantics. Similarly, in vol. V, 2 (XIXe siècle) Shakespeare figures with Aeschylus, Dante and Dostoevsky as one of Claudel's masters (p. 604). On Claudel see, of course, Brunel's thorough study.

${ }^{33}$ Some isolated examples: Discussing Marivaux, Bédier / Hazard remark, after a comparison with Watteau, «on songe aux scènes légères de Shakespeare, que Marivaux ignorait sans doute» (vol. II, p. 45); but this is at best a vague allusion to the comedies. Cherel, having likewise referred to Watteau in connection with Marivaux, speculates more boldly: «[...] peutêtre a-t-il connu les féeries de Shakespeare, et y a-t-il aimé la préciosité du langage et des attitudes d'âme; peut-être a-t-il lu les premières comédies de Corneille» (p. 103). Lalou likens the hero of Maeterlinck's Joyzelle to Prospero (p. 357). Boisdeffre (1958) mentions Audiberti's Mégère apprivoisée «qui na rien à voir avec celle de Shakespeare», indicating that he has Shakespeare's comedy readily in mind (p. 855). Possibly because there was a very successful production of it (I do not know in whose translation) in the seasons of 1950-51 and 1951-52, see Gontard (pp. 257, 259, 279). Ragon (p. 172) was electrified when he read Jean [Marcel] Guéhenno's Caliban parle (1928), but that is a long cry from the play, as is Ragon himself. So much for comedy. It seems that François-Victor Hugo's translation of the Sonnets (1857) was the first, see Duchet (Histoire littéraire, vol. IX, p. 97).

${ }^{34}$ Yet it is significant that Lioure in his round-up of famous midtwentieth-century performances of Shakespeare's plays (pp. 182-3) should only mention tragedies and histories, forgetting even the wonderful production of Le Marchand de Venise by Barrault at the TNP (with himself as Shylock) in 1959-60 which got people off their chairs with enthusiasm at least on the night I watched it. About the Merchant as a problematic 
play, see also below.

35 Klemperer : «Humor und Rousseauismus sind unvereinbar» (18. Jahrhundert, vol. II, p. 241).

${ }^{36}$ See Van Tieghem (p. 118); La Place's translation of The Merry Wives inspired Antoine Bret's comic opera Les Deux amies ou le Vieux coquet, performed without success at the Comédie Italienne in December 1761, while La Place's analysis of The Taming of the Shrew inspired Bret to write the short prose comedy Les Deux Soeurs ou l'Humeur à l'épreuve, performed, likewise without success, for one night in November 1767 at the Théâtre Français. See A.C. Keys, «Shakespeare en France: La mégère apprivoisée en 1767», Revue de littérature comparée 31 (1957), pp. 426-8, based on a longer article in AUMLA 1 (1953).

${ }^{37}$ Mercier : Les tombeaux de Vérone (= Romeo and Juliet) ; Le Vieillard et ses trois filles $(=$ King Lear $)$; I have not read these plays and call them adaptations (rather than translations) following Delon / Mauzi / Menant (p. 55).

${ }^{38}$ See De la littérature (vol. II), esp. 212; also 215 about Falstaff and Pistol as worthless, cf. Wellek's comment (vol. II, p. 222).

${ }^{39}$ The main exception are perhaps some of Musset's comedies, which have been, as Suchier / Birchfeld point out (unfortunately without naming their sources), compared to Shakespeare's. Yet the two critics, who do find some justification for thinking of plays like Caprices de Marianne (1833) as partly alike to Much Ado About Nothing, Twelfth Night, and Love's Labour's Lost, see also important differences (vol. II, p. 357). Barberine (1835), on the other hand, they call a free imitation of Cymbeline (p. 358). These hints would be interesting to follow up.

${ }^{40}$ Vigny also translated Romeo and Juliet and adapted, together with Émile Deschamps, The Merchant of Venice - which in my view belongs to the «dark» or problem comedies (even without the twentieth-century significance of the play which Shakespeare could not foresee); and I am not alone in this judgement, see for other critics my bilingual edition of Much Ado About Nothing / Viel Lärm um Nichts, «Nachwort» (Stuttgart : Reclam, 1993), pp. 375-6, or the monolingual, English version of this : Much Ado About Nothing : A New Critical Edition (Lewiston, NY : Mellen, 1992), «Introduction», pp. 20-1. These two Shakespeare renderings (which were not staged in Vigny's own time, see Braunschvig, p. 552) pale, however, when compared to Othello ou le More de Venise.

${ }^{41}$ For a scathing analysis, see Klemperer (Napoleon bis zur Gegenwart, vol. I, pp. 118-21) on the Preface, esp. p. 120, where he rejects Hugo's view of Christianity and of Shakespeare as essentially antithetic (as did already Suchier and Birch-Hirschfeld, vol. II, p. 347), while Wellek (vol. II, pp. 2545) does not see Hugo as arguing for antithesis only, rather for «a union of opposites, a harmony of contrasts». My impression is that Klemperer is nearer the truth here. 
${ }^{42}$ Which Hugo expressly names (p. 28). The same would apply to King Lear, though not as Rousset (p. 55) presents it, together with Kyd's Spanish Tragedy, viz. as a «tragi-comédie»; could Rousset possibly have had the Lear text of Ducis in mind instead of Shakespeare's ? One does not dare to think so. In any case : he had a noble predecessor in Diderot (see Folkierski, p. 463) ; Diderot expressly mentions Hamlet, - and in that line had a kind of successor in the person of E.M.W. Tillyard, who includes that play among Shakespeare's Problem Plays (London: Chatto \& Windus, 1950, repr. Harmondsworth : Penguin, 1970).

${ }^{43}$ Cf. Barbéris / Duchet (vol. IV, 1), p. 406 «Tous les romantiques essaient de faire du Shakespeare. Le Lorenzaccio de Musset est le meilleur de ces drames».

${ }^{44}$ See Henriot (p. 373) ; Cruickshank (19th Century, p. 102) lays more stress on Richard III.

${ }^{45}$ For details about productions see Jean Jacquot's book; also, e.g. Christopher Smith, «Shakespeare on French Stages in the Nineteenth Century», in Shakespeare and the Victorian Stage, ed. Richard Foulkes (Cambridge : Cambridge U.P., 1986), pp. 223-39.

${ }^{46}$ See e.g. Julij Kagarlizki, Shakespeare and Voltaire, originally in Russian, transl. Manfred Denecke (Dresden : VEB Verlag der Kunst, 1989). Thomas Bestermann has assembled and critically surveyed all the material in Voltaire on Shakespeare, published as vol. LIV of Studies in Voltaire and the Eighteenth Century (Geneva : Institut et Musée Voltaire, 1967).

47 For the later parts of this, Carlencas refers to Pierre-Antoine La Place's Théâtre Anglois. I have checked La Place's «Discours» prefixed to vol. I ([copy of the Bibliothèque de l'Arsenal, Paris] Londres : no publisher, 1746), pp. I-CXVIII and found what I had suspected straightaway: the text does not come from that source. After this passage Carlencas adds something from Riccoboni, likewise acknowledged. It seems to me, however, that there are also reminiscences of Voltaire's «Discours sur la tragédie» prefixed to Brutus (1730), cf. Theâtre, vol. I (Paris : Garnier, n.d.), pp. 311-25, esp. 314 .

48 See also vol. III, pp. 51-2 under «Tragédie», where Voltaire is presented as somewhat bold in advocating more action - in this case, blood - on the stage, though even Voltaire has to admit that Shakespeare is too often disgusting...

${ }^{49}$ Cf. likewise e.g. Petit de Julleville (p. 433). How different Faguet : «Zaïre c'est Othello avec beaucoup de Mithridate ; mais tirer de la jalousie seule cinq actes de tragédie, pour Voltaire ce n'est pas du théâtre» (XVIIIe siècle, p. 263). Cherel (pp. 430-2) sees, by contrast, alongside what is lost also the strengths and beauties of Zaïe, while in Bergez it figures as Voltaire's masterpiece, combining «le dépouillement racinien et le spectaculaire de Shakespeare, la morale édifiante et l'émotion pathétique» 
and showing Voltaire as «un auteur dramatique virtuose» (p. 172). Howarth, on the other hand, discussing Zaïre (p. 34), implicitly follows Faguet's line of argument (esp. p. 264), which pitilessly traces Voltaire's trend to move from tragedy to melodrama and paving the way for vaudeville. Ehrard leaves it at «mélodrame», adding that it answered «parfaitement à l'attente des cours sensibles» (p. 241).

${ }^{50}$ Cf. «Préface» in Voltaire, Theâtre, vol. II (Paris : Garnier, n.d.), pp. 309-11, esp. 309.

51 Most radical in this respect is probably Mornet (Histoire, 1924, see pp. 182-3). A very strong representative of the opposite view is e.g. Braunschvig: «Tout en s'inspirant des grands modèles classiques, il a fortement subi l'influence de Shakespeare» (p. 206). Niklaus (p. 170) takes a balanced view; but his remark (p. 166, note 7) that Voltaire's understanding of Shakespeare «seems penetrating when set by the side of eighteenth-century English criticism of Shakespeare» is wide of the mark.

52 Though Vinet, for one, was still not impressed, approvingly quoting Chateaubriand in the passage calling Racine more natural than Shakespeare and avowing that to read a Shakespeare play without skipping is a pious but tiresome duty - with Dante not faring any better (p. 483).

${ }^{53}$ From this position it is but a step to Suchier / Birch-Hirschfeld, who argue that Voltaire could have learnt a great deal in England if he had not already been so fixedly rooted in his aesthetic convictions (p. 241).

54 A similar gem is found in Barante. Having described the aged Voltaire as an entrenched and embittered literary despot, he says : «Au lieu de ce tableau, l'imagination aime à s'en tracer un autre, et à se représenter Voltaire tel qu'il aurait dû être». For a flight of rhetoric comparable to what Faguet, Lanson and other giants. of the nineteenth-century frequently offer, see e.g. Morçay / Müller about Ronsard and the Pléiade, defending them against Boileau's strictures (p. 273). Such things are rare these days, the more's the pity.

${ }^{55}$ Crystallised in the concept of timidity, see e.g. Pellissier (Précis, p. 324), Sabatier (XVIIIe siècle, p. 180), and Van Tieghem (p. 115). Michèle Duchet / Goulemot (p. 107) talk of a «prudente curiosité». Its importance as a step towards opening out is universally recognised. See e.g. the concise but well-worded statement in Pollmann (p. 43).

${ }_{56}$ Well traced e.g. by Folkierski (pp. 272-5), cf. also Mönch (pp. 278-9).

57 The gist of the argument is repeated on p. 29. As similar approach had been taken by Demogeot in his brief survey of English Romanticism which introduces his account of the French movement. He writes : «À l'aspect de la résurrection du génie germanique, la Grande Bretagne sentit s'émouvoir son vieux sang saxon longtemps engourdi dans ses veines. Elle se ressouvint du grand siècle d'Élisabeth, se reprit à adorer Shakespeare, elle relit ses vieilles ballades» (p. 590). 
${ }^{58}$ In this context, Voltaire's often discussed disappointment and fury at the patronage extended by court circles which to the Le Tourneur's translation assumes a different dimension. For the background to this patronage see esp. Jean Gury, «Shakespeare à la cour de Versailles sous le règne de Louis XVI», Revue de littérature comparée 49 (1975), pp. 103-14.

${ }^{59}$ See e.g. Jasinski himself (vol. II, p. 162), Adam / Lerminier / MorotSir (p. 342), Barbéris / Duchet (vol. IV, 1, p. 133), Bédier / Hazard (vol. II, p. 116), Carré in Grente (p. 552), Sabatier (XIXe siécle, p. 51), etc., varied by Lioure to «pâles contrefaçons» (p. 65).

${ }^{60}$ This may be a remote echo to Gautier's dismissal, in 1844, of Ducis's Othello as «risible», reported by Lioure (p. 72), but laughter was probably near enough to many, - once Ducis's day had passed. For Othello see also below.

61. Martine de Rougemont quotes in this context two reviews of Le Roi Lear, one by Salaun, the other by Geoffroy (pp. 111-2).

${ }^{62}$ Quoted here from the German edition of Cazamian's work (p. 299) : I did unfortunately not have the chance of obtaining the original edition. Indeed, even the Bibliothèque Nationale has no copy of it, according to its catalogue.

${ }^{63}$ For confirmation of this reaction, which seems nearly unimaginable to us, see Gaston Hall, «French Hamlets», New Comparison 2 (Autumn 1986), pp. 42-57. At one point he refers to an (unspecified) «earlynineteenth-century account of Ducis's Hamlet in the Annales Dramatiques » as stating that «cette pièce excite une terreur profonde» (p. 45).

${ }^{64}$ Cf. e.g. also Lintilhac (vol. II, pp. 161-2). This view has also been forcefully and circumspectly been propounded by Smith in Ducis, Othello, ed. Christopher Smith as $\mathrm{n}^{\circ} 80$ of the series Textes littéraires (Exeter: University of Exeter, 1991).

${ }^{65}$ Cf. Wellek (vol. III, p. 42), referring (n. 38) to Sainte-Beuve, Tableau historique et critique de la poésie et du théâtre français au l6e siècle (1828), vol. I, p. 402 ; see also Wolfzettel (p. 182). Suchier / Birch-Hirschfeld, on the other hand, only see in Hardy a contrast to Shakespeare, no similarities (pp. 80-2).

${ }^{66}$ Such speculations lack substance, cf. Van Tieghem, pp. 113-4.

${ }^{67}$ Not counting Vier's general - and really amazing - statement about Jodelle : «Il était né dramaturge mais aussi impresario, et pour être Alexandre Hardy, Shakespeare ou Molière, il ne lui a peut-être manqué que la chance, un mécène ou la santé» (p. 153). These things are of great help to anyone, but I strongly believe that Jodelle lacked a great deal more. I have found no literary history so far to mention Shakespeare in connection with Garnier's Marc Antoine, another obvious move.

${ }^{68}$ Cf. e.g. Bédier / Hazard (vol. II, p. 20), Lancaster (V, p. 4), and Van Tieghem (p. 113). 
${ }^{\theta}$ See Lancaster, vol. V, pp. 70 and, esp. interesting, 109 (Orgon and Shylock), 122 ; Brereton (pp. 76, 197), and Yarrow, e.g. p. 60 (Théophile de Viau), 67 (Hardy), 124-5 (theatres) and, esp. interesting 141 (Tristan l'Hermite) and 142 (Rotrou).

${ }^{70}$ See e.g. what Lanson says about Rotrou : «ll nous fait penser à Shakespeare : il est le seul en son siècle de qui on puisse le dire» (p. 445). This is more illuminating than Ubersfeld and Desné's observation of similarities between the language of Racine's and Shakespeare (p. 313). Further examples are adduced below.

${ }^{7}$ See, apart from those mentioned already, Mercier (p. 115, Mercier's footnote 46, and p. 123), Alexandre Dumas quoted in Lioure (pp. 69-70), Nodier quoted in Barbéris / Duchet (vol. IV, 1, p. 265), Hugo, summarised by Moreau (Romantisme, 1932, p. 201) ; also, somewhat later, Flaubert quoted in Barbéris / Duchet (vol. IV, 4, p. 148).

72 Vier (XVI-XVIIe siècles, p. 332). Further examples: Demogeot (p. 107) enriches his presentation of the influence of Arthurian legends by saying that Shakespeare took several of his subjects from them (naming King Lear). Lalou finds in the first version of Claudel's Tête d'or «des images de la vie humaine qui rappellent directement Macbeth» (p. 490), and Picon calls Claudel's L'Otage (1910) a «drame shakespearien» (p. 24). Both observations should be set into context - see the book by Brunel, but then he specialises in the relationship.

${ }^{73}$ Further examples: Moreau (p. 201) says that Hugo assigns to Shakespeare «le rang suprême, sans renoncer à le partager avec lui» - it is hard to miss the irony here, implying this is unjustified. Very rarely does the yardstick function work to Shakespeare's disadvantage, but Lioure reports on such a case. Maeterlinck's La Princesse Maleine, produced by Antoine in 1890, was «saluée par [Octave] Mirbeau comme 'l'œuvre la plus géniale de ce temps' and 'supérieure en beauté à ce qu'il y a de plus beau dans Shakespeare'» (p. 141).

${ }^{74}$ I have used the 1964, ed. by Bonnefous (pp. 190, 533, 367, 526 ; for further Shakespeare-related entries see pp. 601, 631, 680). Trying to check with the most recent edition I found to my distress that the book is no longer in print. A sad sign of the times, I fear.

75 Warm thanks are due to Maurice Massard (Lyon), who came up with many helpful suggestions. I am also deeply grateful to my young colleagues Carmen Dupovac and Birgit Hatheyer (Salzburg), without whose help in establishing and processing the list of books to use and locating copies in various libraries I could not have undertaken the task. 


\section{Works Cited}

ABRY, Émile, Charles AUDIC, and Paul CrouzET. Histoire illustrée de la littérature française : précis méthodique (Paris : Didier; Toulouse : Privat, 1947).

AdAM, Antoine, Georges LERMINIER, and Édouard MOROT-SIR. Littérature française. 2 vols (Paris : Larousse, 1967-1968).

ALBERT, Paul. La littérature française au dix-huitième siècle (Paris : Hachette, 1874).

Ambrière, Madeleine, ed. Précis de littérature française du XIXe siècle (Paris : Presses Universitaires de France, 1990).

BARANTE, Amable-Guillaume-Prosper Bruguière de. De la littérature française pendant le XVIIIe siècle (Paris : Ladvocat, 1809, 4th edn 1824).

BARBÉRIS, Pierre, and Claude DUCHET, ed. Manuel d'histoire littéraire de la France (gen. ed. Pierre Abraham and Roland Desné). Vol. IV, 1 : 1789-1848 (Paris : Éditions Sociales, 1972).

BARBÉRIS, Pierre, and Claude DUCHET, ed. Manuel d'histoire littéraire de la France (gen. ed. Pierre Abraham and Roland Desné). Vol. IV, 2 : 1789-1848 (Paris : Éditions Sociales, 1972).

BARbÉRIS, Pierre, and Claude Duchet, ed. Histoire littéraire de la France (gen. ed. Pierre Abraham and Roland Desné). Vol. VII : 1794-1830 (Paris : Éditions Sociales, 1976).

BAUER, Roger, with Michael DE GRAAT and Jürgen WeRTHEIMER. Das Shakespeare-Bild in Europa zwischen Aufklärung und Romantik / Jahrbuch für Internationale Germanistik, Reihe A, Kongressberichte, vol. XXII (Bern et al. : Lang, 1988).

Baugh, Albert C., ed. A Literary History of England (London: Routledge \& Kegan Paul, 1948).

BÉDIRR, Joseph, and Paul HAZARD. Histoire de la littérature française illustrée. 2 vols (Paris : Larousse, 1923-1924, repr. 1948). 1995).

Bergez, Daniel, ed. Précis de littérature française (Paris : Dunot,

BERTHAUT, Henri, and Rémi CEILlER. Histoire de la littérature française (gen. ed. Jean Calvet). [Vol. VII] : De Candide à Atala (Paris : del Duca, 1958).

BIENVEnU, Reine. «Shakespeare». In Dictionnaire des littératures de langue française, ed. J.-P. de Beaumarchais, Daniel Couty, and Alain Rey. Vol. III : P-Z (Paris : Bordas, 1984, 2nd edn 1994), pp. 2335-6.

BOISDEFFRE, Pierre de. Une histoire vivante de la littérature d'aujourd'hui (Paris : Perrin, 1958, 7th rev. edn. 1968). See also the new version of this, called Histoire de la littérature de langue française des années 1930 aux années 1980 : Roman - Thêâtre (Paris : Perrin, 1985).

Bonnefous, Raymonde, et al. Guide littéraire de la France (Paris : Hachette, 1964).

BRAUNSCHVIG, Marcel. Notre littérature étudiée dans les textes. 2 vols 
(vol. I : Paris 1933, 24th edn 1962 ; vol. II : Paris : Colin, 1935, 22nd edn, rev. and augm., 1962).

BRERETON, Geoffrey. French Comic Drama from the Sixteenth to the Eighteenth Century (London : Methuen, 1977).

BROCKMEIER, Peter. Darstellungen der französischen Literaturgeschichte von Claude Fauchet bis Laharpe (Berlin : Akademie-Verlag, 1963).

BRUNEL, Pierre. Claudel et Shakespeare (Paris : Colin, 1971).

BRUNETIÈRE, Ferdinand. Les époques du théâtre français, 1636-1850 (1.892 ; new edn Paris: Hachette, 1906).

BRUNETIÈRE, Ferdinand. Histoire de la littérature française. 4 vols (Paris : Delagrave, 1897, new edn 1917).

BusH, Douglas. English Literature in the Earlier Seventeenth Century (Oxford : 1945).

CARlEnCAS, Félix Juvenel de. Essais sur l'histoire des belles lettres, des sciences et des arts. Vol. I (Paris : Frères Duplain, 1749).

CARRÉ, Jean-Marie. «Shakespeare en France au XVIIIe siècle». In Dictionnaire des lettres françaises, gen. ed. Georges Grente ; Le Dixhuitième siècle, vol. II : L-Z, ed. Albert Pauphilet, Louis Pichard, Robert Barroux (Paris: Fayard, 1960), pp. 551-2, rev. edn, ed. François Moreau (1995), pp. 1245-7.

CARTER, Ronald, and John MCRAE. The Routledge History of Literature in English : Britain and Ireland (London : Routledge, 1998, repr. 1999).

CASTEX, Pierre-Georges and Paul SuRER. Manuel des études littéraires françaises. 6 vols [1, II, and III with Georges Becker] (Paris : Hachette, 1946-53).

CASTRES, Antoine Sabatier de. Dictionnaire de la littérature. 3 vols (Paris : Vincent, 1770).

Charlton, D.G., ed. France : A Companion to French Studies (London : Methuen, 1972).

CAZAMIAN, Louis. Geschichte der französichen Literatur, [transl. not named] (Munich : Goldmann, n.d.).

CHARPENTIER, Michel and Jeanne. Littérature : textes et documents (gen. ed. Henri Mitterand) : XVIIIe siècle (Paris : Nathan, 1987).

CHARVET, Patrick Edward. A Literary History of France (gen. ed. Charvet). Vol. IV : The Nineteenth Century, 1789-1870 (London: Benn ; New York: Barnes \& Noble, 1967).

CHATEAUBRIAND, François-René de. Essai sur la littérature anglaise et considérations sur le génie. 2 vols (Paris: 1836). See also CEuvres choisies, ed. Charles Florisoone, 10th edn, rev. Victor-Lucien Tapié (Paris : Hatier, 1948), pp. 445ff.

CHÉNIER, Maria-Joseph. Tableau historique de l'état et du progrès de la littérature française depuis 1789. Paris : Maradan, 1816.

CHEREL, Albert. Histoire de la littérature française (gen. ed. Jean Calvet). Vol. VI : De Télémaque à Candide (Paris : J. de Gigord, 1933). 
CRUICKSHANK, John. French Literature and its Background. Vol. III : The Eighteenth Century (London : Oxford U.P., 1968).

CRUICKSHANK, John. French Literature and its Background. Vol. IV : The Early Nineteenth Century (London : Oxford U.P., 1969).

DÁVIDHÁzI, Péter. The Romantic Cult of Shakespeare. Literary Reception in Anthropological Perspective (London : Macmillan, 1998).

DELON, Michel, Robert MAUzI, and Sylvain MENANT. Littérature française (gen ed. Claude Pichois). Vol VI: De l'Encyclopédie aux méditations, 1750-1820. 2nd edn (Paris : Arthaud, 1989).

DEMOGEOT, Jacques. Histoire de la littérature française depuis ses origines jusqu'à nos jours (Paris: Hachette, 1874).

DES GRANGES, Charles Marc. Histoire illustrée de la littérature française (Paris : Hatier, 1914, 8th edn, 1916).

DIDIER, Béatrice. Littérature française (gen. ed. Claude Pichois). Vol. 11 : Le XVIIIe siècle (Paris : Arthaud, 1976).

DraBble, Margaret, ed. The Oxford Companion to English Literature. Rev. edn (Oxford : Oxford U.P., 1995, repr. 1997). See also Harvey, Paul.

Duchet, Claude, ed. Manuel d'histoire littéraire de la France (gen. ed. Pierre Abraham and Roland Desné). Vol. V : 1848-1917 (Paris : Éditions Sociales, 1977).

DucheT, Claude, ed. Histoire littéraire de la France (gen. ed. Pierre Abraham and Roland Desné). Vol. IX : 1848-1873 (Paris : Éditions Sociales, 1977).

DucheT, Claude, ed. Histoire littéraire de la France (gen. ed. Pierre Abraham and Roland Desné). Vol. X : 1873-1913 (Paris : Éditions Sociales, 1978).

DucheT, Michèle, and J.M. Goulemot, ed. Histoire littéraire de la France (gen. ed. Pierre Abraham and Roland Desné). Vol. V (1) : 1715 1794 (Paris : Éditions Sociales, 1976).

DUMESNIL, René. Histoire de la littérature française (gen. ed. Jean Calvet). Vol. IX : Le réalisme (Paris : J. de Gigord, 1936).

EHRARD, Jean. Littérature française (gen. ed. Claude Pichois). Le XVIIIe siécle (1) : 1720-1750 (Paris : Arthaud, 1974).

ENGLER, Wilfried. Lexikon der französischen Literatur. 3rd edn (Stuttgart : Kröner, 1994).

Faguet, Émile. Dix-huitième siècle (Paris: Société Française d'Imprimerie et de Librairie, n.d. [1890]).

FAGUET, Émile. Dix-neuvième siècle : études littéraires (Paris : Société Française d'Imprimerie et de Librairie, n.d. [1887]).

FLUCHÈRE, Henri. «Shakespeare in France : 1900-1948». Shakespeare Survey 2 (1949), pp. 115-25.

FOLIERSKI, Wlasdislaw. Entre le classicisme et le romantisme (Paris : Champion, 1969).

FRANCE, Peter. «Shakespeare». In The New Oxford Companion to 
Literature in French, ed. Peter France (Oxford: Clarendon Press, 1995), pp. 762-3.

GAUDON, Jean, «1827, December». In Hollier, pp. 644-9.

GAUTIER, Théophile. Histoire du romantisme (1874 ; repr. Milan : La Golliardica, 1970).

GEOFFroy, Julien-Louis. Cours de la littérature dramatique. 4 vols (Paris : Blanchard, 1819). 1839).

GÉRUZEZ, Eugène-Nicolas. Essais d'histoire littéraire (Paris : Hachette,

GONTARD, Denis. La décentralisation théâtrale en France, 1895-1952 (Paris : Société d'Édition d'Enseignement Supérieur, 1973).

GRIMM, Gunter, ed. Literatur und Leser: Theorien und Modelle zur Rezeption literarischer Werke (Stuttgart : Reclam, 1975).

GRIMM, Gunter. Rezeptionsgeschichte: Grundlegung einer Theorie (Munich : Fink, 1977).

HARVEY, Julian, and Janet E. Heseltine. The Oxford Companion to French Literature (Oxford : Clarendon Press, 1959).

HARVEY, Paul. The Oxford Companion to English Literature (London : Oxford U.P., 1932, 3rd edn 1946, repr. 1960). See also Drabble.

HEMPFER, Klaus W. «Voltaire, Baretti und die Kontextabhängigkeit von Rezeptionsaussagen». In Bauer / de Graat / Wertheimer, pp. 77-101.

HENRIOT, Émile, ed. Littérature française des origines à nos jours. 2 vols (Paris : Delagrave, 1958).

HOLliER, Denis, ed. A New History of French Literature (Cambridge, MA : Harvard U.P., 1989).

HoluB, Robert C. Reception Theory : A Critical Introduction (London and New York : Routledge, 1984, repr. 1989).

HowarTh, W.D., Henri M. PEYRE, and John CRUICKSHANK. French Literature from 1600 to the Present (London: Methuen, 1974). [A rev. repr. from Charlton]

HuGo, Victor. Préface de "Cromwell», suivie d'extraits d'autres préfaces dramatiques, ed. Pierre Grosclaude (Paris : Larousse, 1949).

JACQUOT, Jean. Shakespeare en France: mises en scène d'hier et d'aujourd'hui (Paris : Les Temps, 1964).

JASINSKI, René et al. Histoire de la littérature française, rev. edn. 2 vols (Paris : Nizet, 1966).

JAUSS, Hans-Robert. «Literaturgeschichte als Provokation der Literaturwissenschaft» (1970; repr. in Rainer Warning, ed. Rezeptionsästhetik: Theorie und Praxis [Munich : Fink, 1975, 3rd edn 1988], pp. 126-62).

Julleville, Louis Petit de. Histoire de la littérature française des origines à nos jours (Paris : Masson, [1896]).

JUSSERAND, J.J. Shakespeare en France sous l'ancien régime (Paris : Colin, 1898). 
KLEMPERER, Victor. Die französische Literatur von Napoleon bis zur Gegenwart. I : Die Romantik (Leipzig and Berlin : Teubner, 1925).

KLEMPERER, Victor. Die französische Literatur von Napoleon bis zur Gegenwart. II : Der Positivismus (Leipzig and Berlin: Teubner, 1926), pp. 20-2.

KLEMPERER, Victor. Geschichte der französischen Literatur im 18. Jahrhundert. 2 vols (Halle : Niemeyer, 1954-66).

LA HARPE, Jean-François de. Cours de littérature ancienne et moderne. 18 vols (Paris : Dupont, 1825-1826).

LALOU, René. Histoire de la littérature française contemporaine : de 1870 à nos jours (Paris : Crès, 1924).

LANCASTER, Henry Carrington. A History of French Dramatic Literature in the Seventeenth Century. 5 vols (1942; repr. Baltimore, MD : Gordian Press, 1966).

LANSON, Gustave. Histoire de la littérature française (Paris : Hachette, 1894, 5th edn 1898, 11th edn 1909 ; rev. and augm. by Paul Tuffrau, 1953, repr. 1960).

Legouns, Émile and Louis CAZAmian. 1924 ; transl. as A History of English Literature. (1926-1927 ; rev. 1930, augm. 1964 by Raymond Las Vergnas, rev. 1971 ; originally Histoire de la littérature anglaise [Paris : Hachette, 1924 and later]).

LEMERCIER, Népomucène L. Cours analytique de littérature générale. 4 vols (Paris : Nepveu, 1817).

LEVI, Anthony. Guide to French Literature. 2 vols. (Detroit et al. : St James Press, 1994).

LEWIS, C.S. English Literature in the Sixteenth Century Excluding Drama (1944 ; Oxford : Clarendon Press, 1954, repr. 1962).

LINK, Hannelore. Rezeptionsforschung : Eine Einführung in Methoden und Probleme. Stuttgart : Kohlhammer, 1976.

LINTILHAC, Eugène. Précis historique et critique de la littérature française depuis les origines jusqu'à nos jours. 2 vols (Paris : André Guédon / E. André Fils, 1890, 3rd edn 1894).

Lioure, Michel. Le drame de Diderot à Ionesco (Paris : Colin, 1973).

MaguIN, Jean-Marie. «Shakespeare Studies in France since 1960». Shakespeare Yearbook V (1995), pp. 359-73.

MARTINI, Fritz. Deutsche Literaturgeschichte von den Anfängen bis zur Gegenwart. 13th edn (Stuttgart : Kröner, 1965).

MESNARD, Jean, ed. Précis de littérature française du XVIIe siècle (Paris : Presses Universitaires de France, 1990).

MERCIER, Louis-Sébastien. De la littérature et des littérateurs, suivi d'un nouvel examen de la tragédie françoise (1778, repr. Geneva: Slatkine, 1970).

MESSIAEN, Pierre. «Shakespeare au XVIIe siècle». In Dictionnaire des lettres françaises (gen. ed. Georges F. X. M. Cardinal Grente) : Le dix- 
septième siècle, ed. Albert Pauphilet, Louis Pichard, and Robert Barroux (Paris : Fayard, 1954), pp. 950-51.

MöNCH, Walter. Frankreichs Kultur: Tradition und Revolte. Von der Klassik bis zum Surrealismus (Berlin and New York : de Gruyter, 1972).

MORÇAY, Raoul, and Armand Müller. Histoire de la littérature française (gen. ed. Jean Calvet) : La Renaissance (Paris : del Duca, 1960).

MORÇAY, Raoul, and Pierre S AGE. Histoire de la littérature française (gen. ed. Jean Calvet) : Le préclassicisme (Paris : del Duca, 1962).

MOREAU, Pierre. Histoire de la littérature française (gen. ed. Jean Calvet). Vol. VIII : Le romantisme (Paris : J. de Gigord, 1932; see also the new edn, Paris : del Duca, 1957).

MORNET, Daniel. Histoire de la littérature et de la pensée françaises (Paris : Larousse, 1924).

MORNET, Daniel. Histoire de la littérature et de la pensée françaises contemporaines, 1870-1927 (Paris : Larousse, 1927).

Müller, Armand. See Morçay.

NikLAUS, Robert. A Literary History of France (gen. ed. Patrick Edward Charvet). Vol. III : The Eighteenth Century, 1715-1789 (London : Benn ; New York: Barnes \& Noble, 1970).

NISARD, Désiré. Histoire de la littérature française. 4 vols (1844; 15th edn Paris : Firmin-Didot, 1889).

PELLISSIER, Georges. «Le drame shakespearien en France». In Essais de littérature contemporaine (Paris : Société d'Imprimerie et de Librairie, ancienne Librairie Lecène, 1892), pp. 69-109.

Pellissier, Georges. Précis d'histoire de la littérature francaise (Paris : Delagrave, 1907).

PICON, Gaëtan. Panorama de la nouvelle littérature française (Paris : Gallimard, 1949 ; transl. as Panorama der modernen Literatur : Frankreich [Gütersloh : Siegbert Mohn, n.d.]).

POLLMAN, Leo. Geschichte der französischen Literatur: Eine Bewusstseinsgeschichte. Vol. III : Zeitalter des Bürgertums, von 1685-1879 (Wiesbaden : Athenaion, 1978).

POMEAU, René and Jean EHRARD. Littérature française (gen. ed. Claude Pichois). Vol. V : De Fénelon à Voltaire, 1680-1750 (Paris : Arthaud, 1984, end edn 1989).

RAGON, Michel. Histoire de la littérature prolétarienne en France (Paris : Albin Michel, 1974).

RICCOBONI, Louis [Luigi]. Réflexions historiques et critiques sur les différents théâtres de l'Europe (Paris: J. Guérin, 1738).

RIGOLOT, François. «1823 - Stendhal Publishes Racine et Shakespeare... Romantic Historiography» in Hollier, pp. 632-44.

RINCÉ, Dominique, and Bernard LECHERBONNIER. Littérature : textes et documents ; gen. ed. Henri Mitterand (Paris : Nathan, 1986).

Rougemont, Martine de. «Un rendez-vous manqué : Shakespeare et les 
Français au XVIIIe siècle». In Bauer / de Graat / Wertheimer, pp. 102-17.

RousSET, Jean. La littérature de l'âge baroque en France : Circé et le paon (Paris : Corti, 1954).

SABATIER, Robert. Histoire de la poésie française . 6 vols (Paris : Albin Michel, 1975-88).

SAGE, Pierre. See Morçay.

Sainte-Beuve, Charles-Augustin. Euvres, ed. Maxime Leroy. 2 vols (Paris : Gallimard, 1956-60).

SAINTE-B EUVE, Charles-Augustin. Tableau historique et critique de la poésie française et du théâtre français du XVIe siècle (1828; new edn Paris : Charpentier, 1878).

SAMPSON, Gregory. The Concise Cambridge History of English Literature. 2nd edn. augm. by R.C. Churchill (Cambridge : Cambridge U.P., 1961).

SANDERS, Andrew. The Short Oxford History of English Literature (Oxford : Clarendon Press, 1994).

Sola Pinto, V. de. The English Renaissance, 1510-1688 (London: Cresset Press, 1938, 3rd, rev. edn 1966).

STAËL, Germaine de. De la littérature considérée dans ses rapports avec les institutions sociales, ed. Paul Van Tieghem. 2 vols (Geneva: Droz; Paris : Minard, 1959).

STENDHAL [Henri Beyle]. Racine et Shakespeare: Études sur le romantisme, ed. Roger Fayolle (Paris : Garnier-Flammarion, 1970).

SUCHIER, Hermann, and Adolf BIRCH HIRSCHFELD. Geschichte der französischen Literatur von den ältesten Zeiten bis zur Gegenwart. 2nd edn, rev. and augm. 2 vols (Leipzig and Vienna: Bibliographisches Institut, 1913).

TAIlLEFER, Antoine. Tableau historique de l'esprit et du caractère des littérateurs français. 4 vols (Versailles : Poinçot ; Paris : Nyon, 1785).

TAINE, Hippolyte. Histoire de la littérature anglaise. 4 vols (Paris: Hachette,1863-64 ; vol. V, 1890). Also as History of English Literature [transl. not known] (Edinburgh : Edmonston \& Douglas, 1874).

THIBAUDET, Albert. Histoire de la littérature française de 1789 à nos jours, ed. Léon Bopp and Jean Paulhan (Paris : Stock, 1936).

UBERSFELD, Anne, and Roland DESNÉ. Manuel d'histoire littéraire de la France (gen. ed. Pierre Abraham and Roland Desné). Vol. II : 1600-1715 (Paris : Éditions Sociales, 1966).

VAN TIEGHEM, Philippe. Les influences étrangères sur la littérature française, 1550-1880 (Paris: Presses Universitaires de France, 1961).

VIER, Jacques. Histoire de la littérature française : XVIe - XVIIe siècles . (Paris : Colin, 1959).

VIER, Jacques. Histoire de la littérature française : XVIIle siècle. Vol. II : Les genres litéraires et l'éventail des Sciences humaines (Paris : Colin, 1970). 
VINET, Alexandre R. Études sur la littérature française au dix-neuvième siècle. 3 vols (Paris : Ducloux, 1849-51).

VoltaIRE, François Marie Arouet de. Lettres philosophiques, ed. Raymond Naves (Paris: Garnier, 1988); also as Philosophical Letters, transl. Ernest Dilworth (Indianapolis : Bobbs Merrill, 1961).

WARD, A.W. and A.R. W ALLER, ed. The Cambridge History of English Literature. 14 vols (Cambridge : Cambridge U.P., 1907-1916).

WelleK, René. A History of Modern Criticism 1759-1950. 4 vols (Cambridge : Cambridge U.P., vols I and II, 1955, repr. 1981 ; vols III and IV, 1965, repr. 1983).

WILlEMS, Michèle. La genèse du mythe shakespearien, 1660-1780 (Paris : Presses Universitaires de France, 1979).

WOLFZETTEL, Friedrich. Einführung in die französische Literaturgeschichtsschreibung (Darmstadt: Wissenschaftliche Buchgesellschaft, 1982).

YARROW, P.J. A Literary History of France (gen. ed. Patrick Edward Charvet). Vol. II : The Seventeenth Century (London: Benn ; New York: Barnes \& Noble, 1967). 